\title{
Plant regulators and invertase activity in sugarcane at the beginning of the harvest season
}

\section{Reguladores vegetais e atividade de invertases em cana de açúcar no início da safra}

\author{
Glauber Henrique Pereira Leite $^{\mathrm{I}^{*}}$ Carlos Alexandre Costa Crusciol $^{\mathrm{I}}$ \\ Gabriela Ferraz de Siqueira ${ }^{I}$ Marcelo de Almeida Silva ${ }^{I}$
}

\begin{abstract}
Invertases play an essential role in partitioning photosynthates between storage and growth. The objective of this study was to evaluate the activity of acid and neutral invertases and the role they play in controlling the accumulation of sucrose in sugarcane as a result of the application of plant regulators in the beginning of the cropping season.A randomized block experimental design was adopted, with five replicates. The treatments consisted in the application of three plant regulators of the class of growth inhibitors (Sulfomethuron-methyl - 20g ha- , Glyphosate - 0.4L ha- , and Compounds from organic carboxylic radicals + Glyphosate -

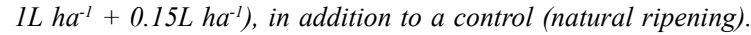
The acid and neutral invertase levels are affected in different ways and intensities, due to the active principle used as ripening agent and to the weather conditions.In sugarcane variety RB85-5453, with the conditions described in this experiment, it is suggested high levels of soluble acid invertase in relation to levels of neutral invertase; however, the first was characterized by high sucrose content in the stalks.Inverse correlation could be established for sugarcane variety RB85-5453 between soluble acid invertase levels and effective sucrose accumulation in the stalks.
\end{abstract}

Key words: Saccharum spp., ripeners, compounds from organic carboxylic radicals, glyphosate, sulfometuronmethyl, cane pol, acid invertase, neutral invertase.

\section{RESUMO}

Invertases desempenham um papel essencial no particionamento de fotossintatos entre armazenamento $e$ crescimento. $O$ objetivo deste estudo foi avaliar a atividade das enzimas invertases ácida e alcalina (neutra) e o papel que desempenham no controle do acúmulo de sacarose em cana-deaçúcar, como resultado da aplicação de reguladores vegetais no início da época de colheita. O delineamento experimental utilizado foi em blocos ao acaso, com cinco repetições. Os tratamentos consistiram na aplicação de três reguladores vegetais da classe dos inibidores de crescimento (Sulfometuron-metil-20g hal ${ }^{l}$, Glifosato - 0,4L $h a^{-1}$, e Compostos de radicais carboxílicos orgânicos + Glifosato -

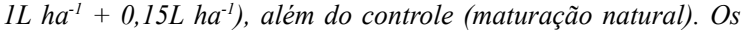
niveis das invertases ácida e neutra são afetados de maneiras e intensidades distintas, devido ao princípio ativo utilizado como agente de maturação e das condições meteorológicas. Para a variedade RB85-5453, nas condições descritas neste experimento, sugerem-se níveis elevados de SAI em relação à NI;no entanto, a primeira foi caracterizada por um elevado teor de sacarose nos colmos. Correlação inversa pode ser estabelecida entre a atividade da invertase ácida e o acúmulo de sacarose.

Palavras-chave: Saccharum spp., maturadores, compostos de radicais carboxílicos orgânicos, glifosato, sulfometuron-metil, pol cana, invertase ácida, invertase neutra.

\section{INTRODUCTION}

Sucrose is a disaccharide composed of one glucose and one fructose molecule. This carbohydrate can undergo acid or enzymatic hydrolysis. The invertase enzyme is responsible for catalyzing sucrose inversion, that is, for providing one glucose and one fructose molecule. The active sucrose accumulation mechanism seems to be the same in sugarcane, regardless of tissue maturity; however, there are differences between tissues (ripe and immature) with respect to sucrose accumulation due to their concentrations of invertases and their need to grow (ALEXANDER, 1973).

Invertases play an essential role in partitioning photosynthates between storage and growth. These enzymes, alone or in combination

\footnotetext{
'Departamento de Produção Vegetal, Faculdade de Ciências Agronômicas (FCA), Universidade Estadual Paulista (UNESP), CP 237, 18610-307, Botucatu, SP, Brasil. E-mail: ghpleite@yahoo.com.br. "Corresponding author.
} 
with planthormones, can regulate many aspects of the growth anddevelopment of plants from gene expression to longdistancenutrient allocation and are involved in regulatingcarbohydrate partitioning, developmental processes, hormone responses and biotic and abiotic interactions (ROITSCH \& GONZÁLEZ, 2004; FOTOPOULOS, 2005).

The sum of invertases from the external space (cell wall) and the vacuole (found at higher amounts and practically in immature tissues only) constitute what is referred to as soluble acid invertase (SAI). SAI activity can be high or low, respectively, under favorable or unfavorable growth conditions (water stress, short photoperiod, low temperatures, application of ripening chemicals) (GAYLER \& GLASZIOU, 1972; LEGENDRE, 1975). According to PAN et al. (2009) SAI activity was considered as the most important in regulating the sucrose content in sugarcane internodes comparing with the enzymes sucrose phosphate synthase (SPS), sucrose synthase (SS) and NI.

In ripe stalk tissues, where growth processes are practically finished, there is a decline in the concentration of acid invertase in the vacuole; neutral invertase (NI) then becomes predominant (enzyme apparently located in the cytoplasm). This enzyme, together with low acid invertase levels in the cell wall, governs active sucrose accumulation in the vacuole. Later, in more mature tissues, which have sucrose content around 15 to $20 \%$, sucrose storage will occur in the intercellular spaces (LINGLE, 1999). According to CHANDRA et al. (2012), in storage sinks, invertase activity isimportant for creating a sucrose concentration gradientfrom the phloem to the sink tissue, and then maintainingthe storage sink for promoting phloemunloading.

Ripening chemicals, which are defined as plant regulators, act by changing the plant's morphology and physiology, and may lead to qualitative and quantitative modifications in production. They may act by slowing down plant growth, allowing increased sucrose contents, early ripening, increased productivity, and also by acting upon the enzymes (invertases) that catalyze sucrose accumulation in the stalks (LAVANHOLI et al., 2002; ALMEIDA et al., 2003). The activity of SAI in young stem tissues seems to be useful as a biochemical parameter to determine the response of sugarcane to the trinexapac-ethyl (GUIMARÃES et al., 2005).

Within this context, the objective of this study was to evaluate the activity of acid and neutral invertases and the role they play in controlling the accumulation of sucrose in sugarcane as a result of the application of plant regulators in the beginning of the cropping season.

\section{MATERIAL AND METHODS}

The experiment was conducted on ratoon cane (2nd cut performed on 04/30/2003) for two consecutive years (2004 and 2005) at São Joaquim Farm, in Igaraçu do Tietê, at São Paulo State (latitude $22^{\circ} 38^{\prime} 45^{\prime}$ 'S, longitude $48^{\circ} 36^{\prime} 29^{\prime \prime} \mathrm{W}$, and elevation $620 \mathrm{~m}$ ), property of Raízen Group. The predominant climate in the region is Aw (Köppen), with a dry, defined climate, mean annual temperature of $21.6^{\circ} \mathrm{C}$, mean relative humidity of $70 \%$, with maximum values of $77 \%$ in February and minimum values of $59 \%$ in August, and a mean precipitation of $1344 \mathrm{~mm}$. The monthly weather data for maximum, medium, and minimum temperatures, precipitation, and wind speed during the period when the experiment was conducted, collected at Fazenda São Joaquim's Weather Station, are presented in figure 1.

The experimental design consisted of randomized blocks, with five replicates. The treatments consisted in the application of three plant regulators of the class of growth inhibitors (Sulfomethuron-methyl, Glyphosate, and Compounds from organic carboxylic radicals (C.C.) + Glyphosate), as well as a control (natural ripening). The commercial products used were Curavial, Roundup, and MTD + Glyphosate, respectively, applied at the dose recommended by the manufacturers, i.e., $20 \mathrm{~g} \mathrm{ha}^{-1}, 0.4 \mathrm{~L} \mathrm{ha}^{-1}$, and $1 \mathrm{~L}$ $\mathrm{ha}^{-1}+0.15 \mathrm{~L} \mathrm{ha}^{-1}$ respectively, without the addition of adjuvants. Each plot consisted of 8 rows (10m long), spaced at $1.5 \mathrm{~m}$. However, for evaluation purposes, only the central 6 rows were considered, disregarding $1 \mathrm{~m}$ at the extremities, for a usable area of $72 \mathrm{~m}^{2}$.

Variety RB85-5453 was used, known for its medium stalk productivity, high sucrose content and early maturation, and medium soil fertility requirements (UNIVERSIDADE FEDERAL DE SÃO CARLOS, 1998). The plant regulators were applied on $03 / 29 / 2004$ and on $03 / 29 / 2005$ with a $\mathrm{CO}_{2}$-pressurized backpack sprayer equipped with a $6 \mathrm{~m}$-long, T-shaped boom, containing six AXI 11002 spray nozzles, at a working pressure of 50 PSI for a $100 \mathrm{~L} \mathrm{ha}^{-1}$ flow.

Four sampling seasons were established throughout the experimental period for the biochemical measurements at $0,30,60$, and 90 days after application (DAA). A similar procedure was adopted in the 2005 cropping season for the technological determination; however, in 2004 evaluations were made at $0,15,30,45,60,75$, and 90 DAA, totaling 7 seasons.

One meter was established at random in the usable area at each sampling season; the stalks were collected, topped at apical bud height, and 

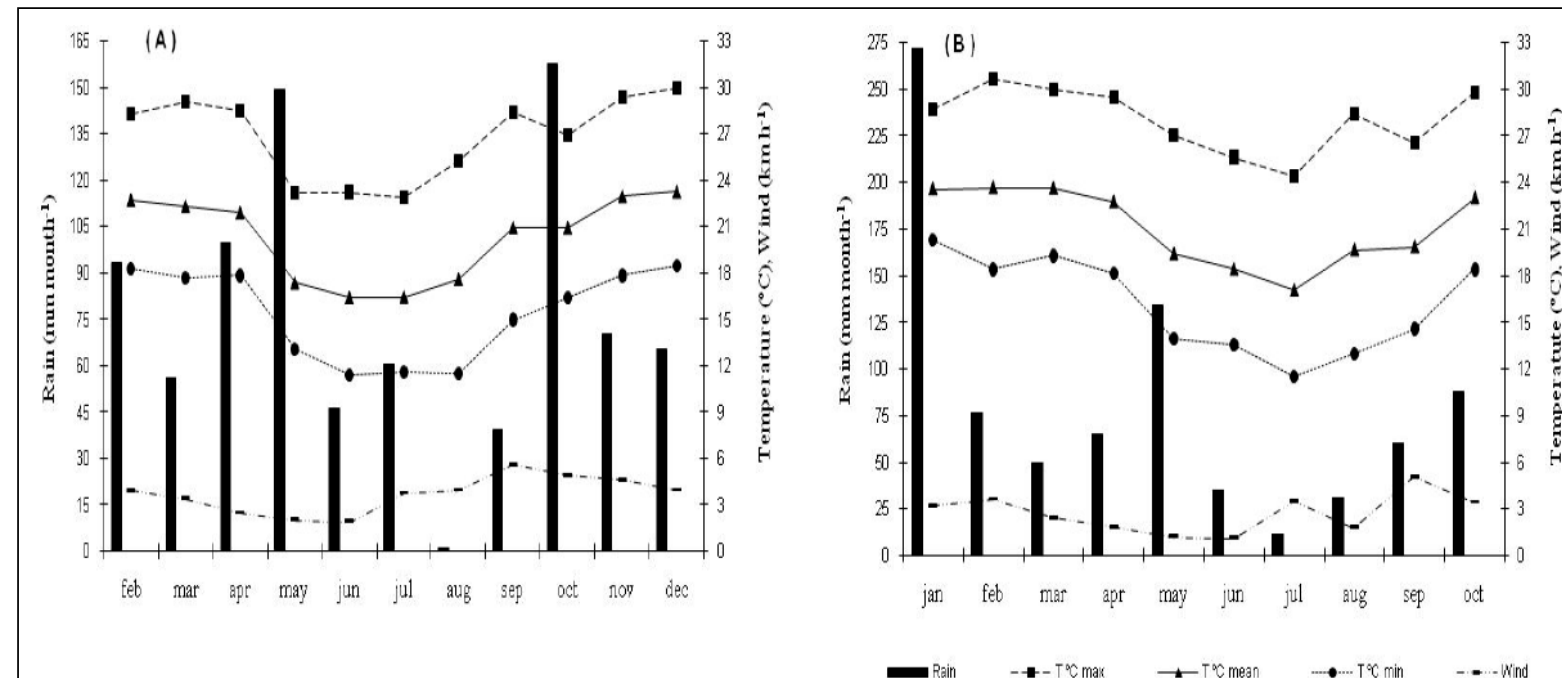

Figure 1 - Precipitation $\left(\mathrm{mm}\right.$ month $\left.^{-1}\right)$, maximum, medium, and minimum temperatures $\left({ }^{\circ} \mathrm{C}\right)$, and wind speed $\left(\mathrm{km} \mathrm{h}^{-1}\right) \mathrm{recorded}$ at $\mathrm{São}$ Joaquim farmweather station during the period in which the experiment was conducted in the 2004 (A) and 2005 (B) cropping seasons, Igaraçu do Tietê, São Paulo State, Brazil.

defoliated and then forwarded to the Biochemical Analyses Laboratory at Departament of Chemistry and Biochemistry, Biosciences Instituteat UNESP, and to the Beverage Laboratory at Department of Agroindustrial Management and Technology, College of Agronomic Sciencesat UNESP, for biochemical and technological determinations according to the methodology defined in theSucrose Content-Based Sugarcane Payment System, in accordance with Consecana's semiannual updates for the technological evaluations, described in FERNANDES (2003), considering the cane pol parameter.

Soluble acid (SAI) and neutral (NI) invertase determinations were performed after milling the stalks to obtain the crude extract. Specific isozyme extracts were prepared according to the methodologies described by Hatch et al. (1963), RICARDO \& REES (1970) and VIEIRA et al. (1996). Five-mL aliquots (obtained after filtering the juice at low temperature) were taken and added to $5 \mathrm{~mL} 1 \mathrm{mM}$ mercaptoethanol buffer, $\mathrm{pH}$ 7.5. After centrifugation at $10,000 \mathrm{rpm}$ for 30 minutes at $4^{\circ} \mathrm{C}$, the supernatant was separated and the precipitate was added of $5 \mathrm{~mL}$ $5 \mathrm{mM}$ sodium phosphate buffer, $\mathrm{pH} 7.0$ and then again centrifuged at $10,000 \mathrm{rpm}$ for 30 minutes at $4^{\circ} \mathrm{C}$. NI and SAI activity was determined according to adaptations to the methodologies proposed by HATCH et al. (1963), RICARDO \& REES (1970), and VIEIRA et al. (1996). For the NI reaction, it was used $1.25 \mathrm{~mL}$ of the extract, $6.25 \mathrm{~mL}$ of $50 \mathrm{mM}$ sodium phosphate buffer, $\mathrm{pH} 7.5$, and $2.5 \mathrm{~mL} 200 \mathrm{mM}$ sucrose. The reaction system took place in a double boiler $\left(37^{\circ} \mathrm{C}\right)$ for 30 minutes. Upon cooling, $1 \mathrm{~mL}$ Somogyi's reagent was added and the medium was taken to the double boiler $\left(37^{\circ} \mathrm{C}\right)$ for another 10 minutes. Later, $1 \mathrm{~mL}$ Nelson's reagent was added, and readings were taken in a UV/VIS spectrophotometer at $530 \mathrm{~nm}$. For the SAI reaction, it was used $1.25 \mathrm{~mL}$ of the extract, $6.25 \mathrm{~mL}$ of $50 \mathrm{mM}$ sodium acetate buffer, $\mathrm{pH} 4.5$, and $2.5 \mathrm{~mL} 200 \mathrm{mM}$ sucrose. The reaction system took place in a double boiler $\left(37^{\circ} \mathrm{C}\right)$ for 30 minutes. Upon cooling, $1 \mathrm{~mL}$ Somogyi's reagent was added and the medium was incubated in a double boiler $\left(37^{\circ} \mathrm{C}\right)$ for another 10 minutes. Later, $1 \mathrm{~mL}$ Nelson's reagent was added, and readings were taken in a UV/VIS spectrophotometer at $530 \mathrm{~nm}$.

The results were submitted to analysis of variance, and treatment means were compared by the LSD test at $5 \%$ probability. The sampling season results were submitted to regression analysis, and the criterion adopted to select a model was the magnitude of regression coefficients that were significant at 5\% probability by the $t$ test.

\section{RESULTS AND DISCUSSION}

During the period in which the experiment was conducted, in the year 2004, the weather conditions favored sugarcane vegetative development, with adequate water availability and temperatures; precipitation decreased only from July on, although temperatures declined since April (Figure 1A). On the other hand, in 2005 the weather conditions favored the natural ripening process, as a result of reduced water availability and temperatures (Figure 1B). 
In general, acid isozyme activity was higher than neutral isozyme activity; above all, activity was influenced with distinct characteristics for each treatment (Figures 2A, 2B, 2D, and 2E). This observation allows to infer that the weather conditions favorable to plant vegetative development in 2004 (Figure 1) probably required sugars (glucose and fructose) to maintain metabolism.

With regard to the acid isozyme, high acid isozyme levels, as evidenced by some research results, may be associated with the function of this enzyme in the regulation of growth in immature tissues; a positive correlation can be established between acid invertase activity and elongation rate (VIEIRA et al., 1996; LINGLE, 1999).

JOSHI et al. (2013) observed reduced SAI activity 12 months after planting (MAP) in all portions of the cane but after 13 MAP was noticed a slight increase at top and bottom internodes. Further increase may lead to remobilization of stored sucrose for growth and maintenance of cellular process, due to the reduced amount of photosynthate production after maturity, indicating decrease in the sucrose content in the matured tissues during 13 MAP.
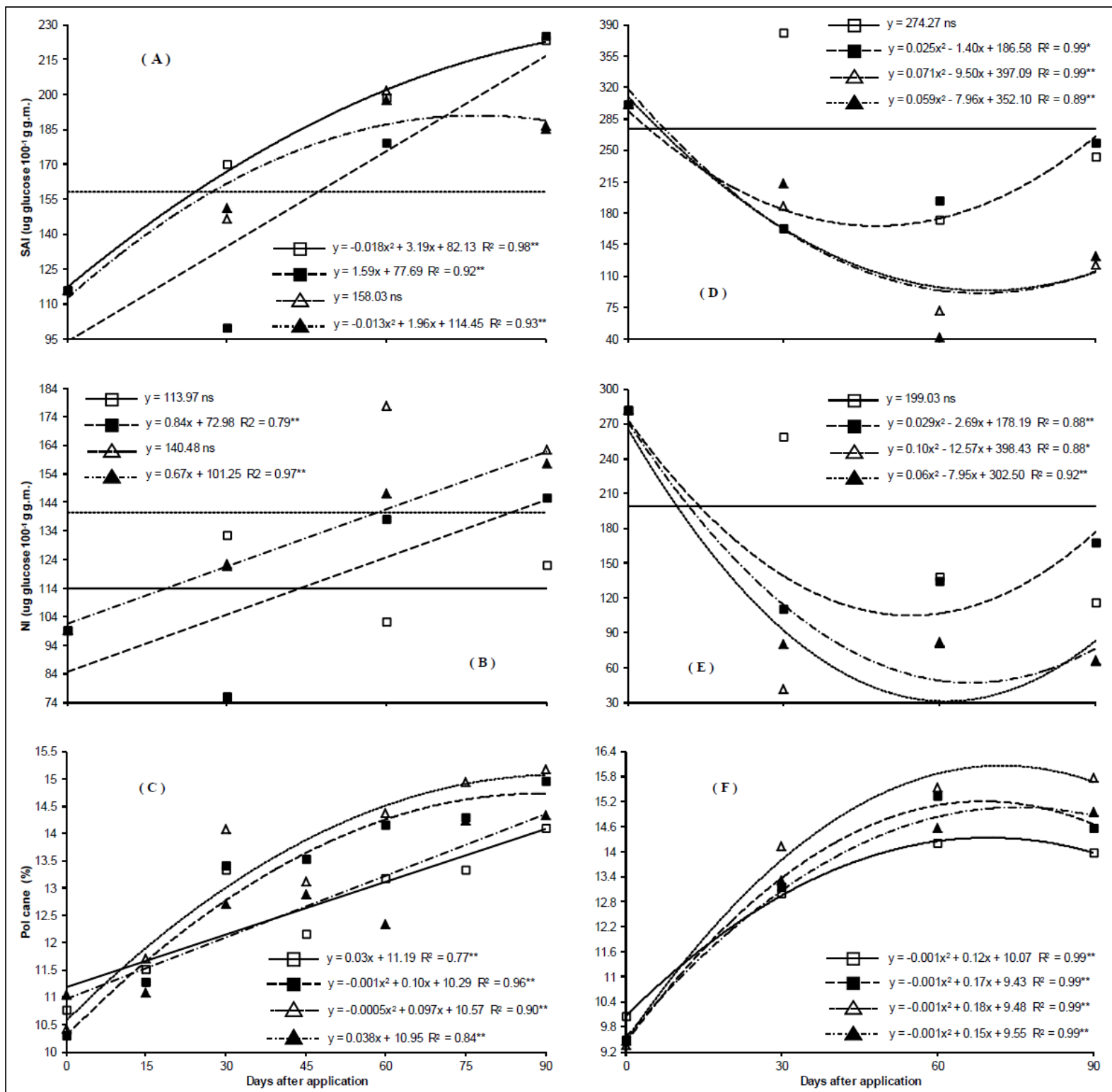

Figure 2 - Acid and neutral invertases ( $\mu \mathrm{g}$ glucose $100 \mathrm{~g}^{-1}$ green matter), and Pol cane (\%) with the application of control ( $\square$ ), Sulfometuron methyl (घ), Glyphosate $(\Delta)$, and C.C. + Glyphosate $(\boldsymbol{\Delta})$ treatments in sugarcane variety RB855453, Igaraçu do Tietê, São Paulo,

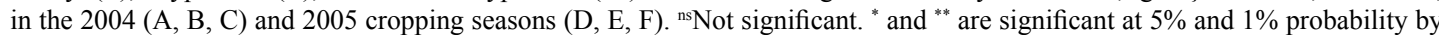
the LSD test, respectively. 
There is evidence of high neutral isozyme levels for the acid isozyme; such relation could be closely associated with the plant's capacity of accumulating sucrose in ripe internodes (RICARDO \& SOVIA, 1974). In the same way, VIEIRA et al. (1996) observed lower acid isozyme activity levels for the neutral isozyme in stalks of many sugarcane varieties, in addition to a tendency of decline with plant physiological development. JOSHI et al. (2013) noted higher acid invertase activity in immature internodes irrespective of the variety and months after planting.

In 2004, plants treated with Sulfomethuronmethyl had a linear increase in SAI and NI levels as sampling seasons progressed (Figures 2A and 2B); a similar behavior pattern was observed for NI in the C.C. + Glyphosate treatment (Figure 2B). In that period, the SAI levels for the control and C.C. + Glyphosate treatments showed responses that can be expressed by a positive quadratic model (Figure 2A); in the latter, maximum enzymatic activity was determined at 78 DAA $\left(190.97 \mu \mathrm{g}\right.$ glucose $100 \mathrm{~g}^{-1}$ green matter), while the Glyphosate treatment did not influence enzymatic activity (Figures 2A and 2B).

In 2005, the treatments significantly influenced enzymatic behavior pattern as sampling seasons progressed, fitting quadratic equations, except for the control (Figures 2D and 2E). The lowest SAI levels were $166.60,80.13$, and $88.53 \mu \mathrm{g}$ glucose $100 \mathrm{~g}^{-1}$ green matter for the Sulfomethuronmethyl treatments at 28 DAA, while Glyphosate and C.C. + Glyphosate achieved the lowest levels at 67 DAA (Figure 2D). For NI, reduced enzymatic activity occurred at 62,66 , and 46 DAA, with values of 40.76 , 41.92 , and $112.45 \mu \mathrm{g}$ glucose $100 \mathrm{~g}^{-1}$ green matter in the treatments consisting of Glyphosate, C.C. + Glyphosate, and Sulfomethuron-methyl (Figure 2E).

LEITE et al. (2009) reported high correlation between the invertases activity and the weather conditions at the middle of the season where the acid activity was higher in weather conditions favorable to plant vegetative development and when the weather conditions were favorable to natural ripening the neutral invertases activity increased.

According to GAYLER \& GLASZIOU (1972) and LINGLE (1999), SAI activity is responsiblefor the variations in sugar contents during growth, since it seems to be closely and inversely related to sucrose and total sugars contents. There have been reports of correlation between low acid isozyme levels under low temperature conditions (winter) and an increase in sucrose content during the sugarcane ripening process (ZHU et al., 1997; TERAUCHI et al., 2000); however, ROSE
\& BOTHA (2000) demonstrated a significant correlation between sucrose content and NI level. PAN et al. (2009), studying the key enzymes in regulating sucrose accumulation, reported positively correlation between SPS activity and sucrose content in the internode while SAI, SS and NI were found negatively correlated with the sucrose content in two sugarcane cultivars.

The sugarcane stalks in variety RB85-5453 accumulated significant amounts of sucrose after the ripening chemicals were applied; distinct intensities could be observed in the various treatments. Figure $2 \mathrm{C}$ shows an increase in sucrose contents as the sampling seasons progressed; the control and C.C. + Glyphosate treatments fitted linear equations, while the Glyphosate and Sulfomethuron-methyl treatments fitted the positive quadratic model.In 2005, a similar behavior pattern was observed for this variable, and the treatments were adjusted to positive quadratic models (Figure 2F). This increase in sucrose is best represented by quadratic equations, since the plant tends to resume vegetative development when the environment provides favorable conditions.

In 2005, the Glyphosate and Sulfomethuron-methyl treatments provided maximum sucrose accumulation at 70 DAA (cane pol $=17.30 \%$, cane pol $=16.30 \%$, respectively); in the C.C. + Glyphosate and control treatments, such increase was observed at 73 (cane pol= $14.90 \%$ ) and 68 DAA (cane pol $=13.80 \%$ ), respectively (Figure $2 \mathrm{~F}$ ).

In the Glyphosate treatment, this effect can probably be explained by the low calculated SAI level, which occurred at 67 DAA $(80.13 \mu \mathrm{g}$ glucose $100 \mathrm{~g}^{-1}$ green matter) (Figure 2D), although reduced NI activity $\left(40.76 \mu \mathrm{g}\right.$ glucose $100 \mathrm{~g}^{-1}$ green matter) was determined at 62 DAA (Figure 2E), allowing the increase in sucrose concentration in the stalks to be attributed to the reduction in SAI activity. This correlation was also observed for the C.C. + Glyphosate treatment, since the lowest activity of the SAI (Figure 2D) and NI isozymes (Figure 2E) occurred at 67 $\left(88.53 \mu \mathrm{g}\right.$ glucose $100 \mathrm{~g}^{-1}$ green matter) and $66 \mathrm{DAA}$ (41.92 $\mu \mathrm{g}$ glucose $100 \mathrm{~g}^{-1}$ green matter), respectively.

According to SU et al. (1992), the use of Glyphosate as ripening agent in sugarcane provided a reduction in acid invertase levels, concurrently with a reduction in immature internode elongation rate, resulting in increased sucrose concentration.GUIMARÃES et al. (2005) reported that trinexapac-ethyl, as ripener in sugarcane, reduced the activity of soluble acid invertase in the youngest internodes but no effect was found in older tissues. On the other hand, HAWKER (1985) stated that 
sugarcane varieties that retain SAI as their main invertase form do not store high levels of sucrose.

\section{CONCLUSION}

The acid and neutral invertase activity levels were affected in different ways and intensities, due to the active principle used as ripening agent and to the weather conditions.In sugarcane variety RB855453, with the conditions described in this experiment, it is suggested high levels of soluble acid invertase in relation to levels of neutral invertase; however, the first was characterized by high sucrose content in the stalks. Inverse correlation could be established for sugarcane variety RB85-5453 between soluble acid invertase levels and effective sucrose accumulation in the stalks.

\section{ACKNOWLEDMENTS}

To the Fundação de Amparo à Pesquisa do Estado de São Paulo (FAPESP) for financial support (2003/119069), to the Conselho Nacional de Desenvolvimento Científico e Tecnológico $(\mathrm{CNPq})$, for an award for excellence in research of the secondauthor, and to Raízen Group, for providing the area where the experiments were carried out.

\section{REFERENCES}

ALEXANDER, A.G. Sugarcane physiology: a comprehensive study of the Saccharum source-to-sink system. Amsterdam: Elsevier, 1973. 752p

ALMEIDA, J.C.V. et al. Eficiência agronômica de sulfomethuronmethil como maturador na cultura da cana-de-açúcar. Stab, v.21, p.36-37, 2003. Available from: <http://177.103.158.171/ pdf/21.3.2.pdf $>$. Accessed: Jul. 10, 2014.

CHANDRA, A. et al. Complexities of invertases controlling sucrose accumulation and retention in sugarcane. Current Science, v.102, p.857-866, 2012. Available from: <http:/www.currentscience.ac.in/ Volumes/102/06/0857.pdf>. Accessed: Aug. 21, 2014.

FERNANDES, A.C. Cálculos na agroindústria da cana-deaçúcar. Piracicaba: STAB, 2003. 240p.

FOTOPOULOS, V. Plant invertases: structure, function and regulationof a diverse enzyme family. Journal of Biological Research, v.4, p.127-137, 2005. Available from: <http://www.jbr gr/papers20052/02-Fotopoulos.pdf>. Accessed: Sept. 10, 2014.

GAYLER, K.R.;GLASZIOU, K.T. Physiological functions of acid and neutral invertases in growth and sugar storage in sugar cane. Physiologia Plantarum, v.27, p.25-31, 1972. Available from: $<$ http://onlinelibrary.wiley.com/doi/10.1111/j.1399-3054.1972. tb01131.x/abstract>. Accessed: Sept. 16, 2013. doi: 10.1111/ j.1399-3054.1972.tb01131.x.

GUIMARÃES, E.R. et al. Sugarcane growth, sucrose accumulation and invertase activities under trinexapac-ethyl treatment Científica, v.33, p.20-26, 2005. Available from: <http://cientifica. org.br/index.php/cientifica/article/view/60/43>. Accessed: Aug. 21, 2014. doi: 10.15361/1984-5529.2005v33n1p20-26.
HATCH, M.D. et al. Sugar accumulation cycle in sugarcane. I. Studies on enzymes of the cycle. Plant Physiology, v.38, p.338-343, 1963. Available from: <http://www.ncbi.nlm.nih. gov/pmc/articles/PMC549927/pdf/plntphys00419-0102.pdf>. Accessed: May 12, 2012.

HAWKER, J.S. Sucrose. In: DEY, P.M.; DIXEN, R.A. (eds.). Biochemistry of storage carbohydrates in green plants. London: Academic, 1985. p.1-48.

JOSHI, J.B. et al. Activities of enzymes involved in synthesis and degradation of sucrose in popular sugarcane varieties. Asian Journal of Experimental Biological Science, v.4, p.237-244, 2013. Available from: <http://www.ajebs.com/vol4\%282\%29/11. pdf>. Accessed: Aug. 21, 2014.

LAVANHOLI, M.G.D.P. et al. Aplicação de Ethephon e Imazapyr em cana-de-açúcar em diferentes épocas e sua influência no florescimento, acidez do caldo e teores de açúcares nos colmos variedade SP70-1143. Stab, v.20, p.42-45, 2002.

LEGENDRE, B.L. Ripening of sugarcane: effects of sunlight, temperature, and rainfall. Crop Science, v.15, p.349-352, 1975. Available from: <https://www.crops.org/publications/cs/ abstracts $/ 15 / 3 /$ CS0150030349?access $=0 \&$ view $=$ pdf $>$. Accessed: Feb. 20, 2007. doi: 10.2135/cropsci1975.0011183X001500030020x.

LEITE, G.H.P. et al. Reguladores vegetais e atividade de invertases em cana-de-açúcar em meio de safra. Ciência Rural, v.39, n.3, p.718-725, 2009. Available from: $<$ http://www.scielo. $\mathrm{br} / \mathrm{scielo}$.php?pid=S0103-84782009000300014\&script $=\mathrm{sci}$ arttext $>$. Accessed: Feb. 20, 2007. doi: 10.1590/S010384782009000300014

LINGLE, S.E. Sugar metabolism during growth and development in sugarcane internodes. Crop Science, v.39, p.480-486, 1999. Available from: <https://www.crops.org/publications/cs/abstracts/39/2/CS 0390020480 access $=0 \&$ view $=$ pdf $>$. Accessed: Feb. 20, 2007. doi: 10.2135/cropsci1999.0011183X0039000200030x.

PAN, Y. et al. Soluble acid invertase and sucrose phosphate synthase: Key enzymes in regulating sucrose accumulation in sugarcane stalk. Sugar Tech, v.11, p.28-33, 2009. Available from: <http:// link.springer.com/article/10.1007\%2Fs 12355-009-0005-9>. Accessed: Aug. 21, 2014. doi:10.1007/s12355-009-0005-9.

RICARDO, C.P.P.; SOVIA, D. Development of tuberous roots and sugar accumulation as related to invertase activity and mineral nutrition. Planta, v. 118, p.43-55, 1974. Available from: <http:// link.springer.com/article/10.1007\%2FBF00390502>. Accessed: Feb. 20, 2007. doi: 10.1007/BF00390502.

RICARDO, C.P.P.; REES, T. Invertase activity during the development of carrot roots. Phytochemistry, v.9, p.239-247, 1970. Available from: <http://www.sciencedirect.com/science/ article/pii/S0031942200851304>. Accessed: Jun. 12, 2010. doi: 10.1016/S0031-9422(00)85130-4

ROITSCH,T.; GONZÁLEZ, M.C. Function and regulation of plant invertases: sweet sensations. Trends in Plant Science, v.9, p.606-613, 2004. Available from: <http://www.sciencedirect.com/ science/article/pii/S136013850400250X >. Accessed: Mar. 21, 2003. doi: 10.1016/j.tplants.2004.10.009.

ROSE, S.; BOTHA, F.C. Distribution patterns of neutral invertase and sugar content in sugarcane internodal tissues. Plant Physiology and Biochemistry, v.38, p.819-824, 2000. Available from: <http:// 
www.sciencedirect.com/science/article/pii/S0981942800011906>. Accessed: Jun. 12, 2010. doi: 10.1016/S0981-9428(00)01190-6.

SU, L.Y. et al. The relationship of glyphosate treatment to sugar metabolism in sugarcane: new physiological insights. Journal of Plant Physiology, v.140, p.168-173, 1992. Available from: <http:// www.sciencedirect.com/science/article/pii/S0176161711809296>. Accessed: Sept. 18, 2008. doi: 10.1016/S0176-1617(11)80929-6.

TERAUCHI, T. et al. Activity of sucrose phosphate synthase in relation to sucrose concentration in sugarcane internodes. Japanese Journal of Tropical Agriculture, v.44, p. 141-151, 2000.

UNIVERSIDADE FEDERAL DE SÃO CARLOS. Catálogo de variedades RB. São Carlos: Departamento de Biotecnologia Vegetal.1998. Não paginado. (Apostila).
VIEIRA, I.M.S. et al. Níveis de açúcares e atividade de invertases em cana-de-açúcar (Saccharum officinalis spp.). I. Cultivares 'NA5679' e 'CB41-76'. Revista de Agricultura, v.71, p.67-92, 1996.

VIEIRA, I.M.S. et al. Níveis de açúcares e atividade de invertases em cana-de-açúcar (Saccharum spp.). II. Cultivares 'SP70-1143' e 'SP71-799'. Revista de Agricultura, v.71, p. 197-224, 1996.

ZHU, Y.J. et al. Sucrose accumulation in the sugarcane stem is regulated by the difference between the activities of soluble acid invertase and sucrose phosphate synthase. Plant Physiology, v.115, p.609-616, 1997. Available from: <http://www.plantphysiol. org/content/115/2/609.full.pdf + html $>$. Accessed: May. 25, 2006. doi: 10.1104/pp.115.2.609. 